\title{
PATHOGENIC AND DRUG RESISTANT BACTERIA IN RAW MILK OF JESSORE CITY: A POTENTIAL FOOD SAFETY THREAT
}

\author{
U. T. Tasnim and M. T. Islam \\ Department of Microbiology, Jessore University of Science and Technology, Jessore 7408, Bangladesh
}

\begin{abstract}
Milk is such a food which can meet almost all nutritional needs of human lives. Raw or unprocessed milk supports the growth of wide variety of microorganisms. The major interests of this study were examining the microbial quality of raw milk collected from different locations of Jessore city in Bangladesh and determining antibiotic susceptibility pattern of some isolated bacteria. To do so, 12 raw milk samples were collected from different areas of Jessore city. Microbial analysis comprised of enumeration of TVC (total viable count), TCC (total coliform count) and TSC (total staphylococcal count). The highest TVC, TCC and TSC were $1.95 \times 10^{9} \mathrm{CFU} / \mathrm{ml}, 2.5 \times 10^{7} \mathrm{CFU} / \mathrm{ml}$ and $1.02 \times 10^{7} \mathrm{CFU} / \mathrm{ml}$ respectively. Prevalent bacterial populations were Klebsiella spp., Enterobacter spp., Shigella spp. Staphylococcus spp., Escherichia coli and Citrobacter spp. In order to observe the antibiotic susceptibility pattern, the antibiotic sensitivity test was performed for some randomly selected isolates of E. coli and Klebsiella spp. More than $90 \%$ isolates of Klebsiella spp. were found to be resistant against Erythromycin whereas more than $90 \%$ isolates were sensitive against Imipenem. On the other hand, $100 \%$ E. coli isolates were observed as resistant against Erythromycin and in case of Trimethopreme 100\% isolates were sensitive. Multidrug resistance pattern was also found. These results suggest the necessity of hygienic practices during handling, processing and post-processing of raw milk to improve the microbiological quality and safety of raw milk.
\end{abstract}

Key words: Antibiotic resistance, Bacterial load, Milk quality.

\section{INTRODUCTION}

Milk has a major contribution in human diet. It also plays as excellent culture medium for many kinds of microorganisms. Because of nutritional value, milk is called 'Ideal Food', which is synthesized in specialized cells of the mammary gland and virtually sterile when secreted into the alveoli of the udder (Tolle, 1980). However, it contains relatively few bacteria when it leaves the udder of a healthy animal and generally these bacteria do not grow in milk under the usual conditions of handling (Frazier et al., 2003). Several authors claimed some possibilities for contamination of raw milk. Like, during the normal milking operation, contamination occurs from the udder itself, especially the exterior of the udder and adjacent areas of udder play critical role for contamination (Bramley and McKinnon, 1990). In addition, the number and types of microorganisms in milk immediately after milking are affected by biotic factors like animal health and its cleanliness and abiotic factors such as air, soil, grass, feces, season and milking equipment (Uddin et al., 2011). It is also hypothesized that differences in feeding and housing strategies of animals may influence the microbial quality of milk (Coorevits, 2008). Besides, rinsing water for milking machine and milking equipment washing may also be responsible for the presence of high number of microorganisms including pathogens in raw milk (Bramley and McKinnon, 1990). Public health problems associated with the consumption of unpasteurized raw milk and its products have been well documented (De Valk et al., 2000; De Buyser et al., 2001 and Harrington et al., 2002). So, examination for the presence and number of specific microorganisms is therefore an integral part of any quality control or quality assurance plan.

The detection of coliform bacteria or pathogens in milk can be used as an indicator for udder infection (mastitis), contamination in milking utensils or water supply (Bonfoh et al., 2003). These infections need a wide variety of antibiotics to be treated. It is hypothesized that the indiscriminate use of antibiotics may lead to the development of multiple antibiotics resistance thereby rendering the antibiotic treatment ineffective (Johnston $e t$ al., 1983). According to the Infectious Diseases Report released by the World Health Organization (WHO) in 2000, drug resistant organisms are prevalent worldwide.

Over many years considerable attention has been paid to improve the quality of milk particularly the hygienic quality throughout the world. In Bangladesh, milk is produced in urban and rural areas mostly in non-organized

*Corresponding e-mail address: mt.islam@just.edu.bd

Copyright (c) 2015 Bangladesh Society for Veterinary Medicine

All rights reserved 0329/2015 


\section{U. T. Tasnim and M. T. Islam}

way and usually supplied to the consumers in raw form. For many reasons, contamination in raw milk has never been possible to avoid yet (Uddin et al., 2011 and Khaton et al., 2014). Due to the serious implications from the raw milk consumption and increasing concern of resistance of pathogenic bacteria to antibiotics; this current study therefore aimed to find out the prevalence and antibiotic susceptibility pattern of pathogens in raw milk supplied in the city of Jessore, Bangladesh.

\section{MATERIALS AND METHODS}

\section{Sample collection}

A total of 12 raw milk samples were collected for microbial analysis from Jessore city and its surrounding areas during the period of January to June, 2014. About $100 \mathrm{ml}$ of fresh raw milk were collected in a sterile sample container using a sample collector ice box at $4^{\circ} \mathrm{C}$ and were transported to the laboratory without delay.

\section{Isolation and enumeration of bacteria}

The bacterial count was performed by standard plate count method (ICMSF, 1986). The microbiological conditions of safety and hygiene were then assessed using the methods recommended by International Commission on Microbiological Specifications for Foods (ICMSF, 1986). Serial dilutions of samples were made up to $10^{-7}$ in sterile normal water. Bacterial count was carried out by the spread plate technique. The sample $(0.1 \mathrm{ml})$ of each dilution was taken onto each sterile petridish and evenly spread on different culture medium and incubated at $37{ }^{\circ} \mathrm{C}$ for 24 hours. Total viable count (TVC), total coliform count (TCC) and total staphylococcal count (TSC) were done for enumeration using Nutrient Agar, MacConkey Agar and Mannitol Salt Agar respectively. Bacterial isolates were then identified according to the Bergey's manual of determinative bacteriology (Buchanan and Gibbon, 1984).

\section{Antibiogram}

Kirby-Bauer method (Bauer et al., 1966) was used in this study to examine bacterial susceptibility to antimicrobial agents on Mueller-Hinton agar. Tested antibiotics were Amoxycillin (AML, 10 $\mu \mathrm{g}$ ), Ceftriaxone

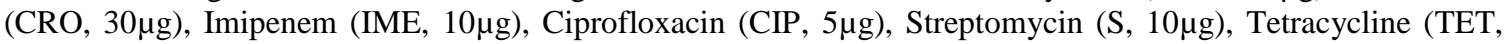
$30 \mu \mathrm{g})$, Gentamicin $(\mathrm{CN}, 10 \mu \mathrm{g})$, Nalidixic acid (NA, $30 \mu \mathrm{g})$, Chloramphenicol (C, 30 $\mu \mathrm{g})$, Trimethoprim-

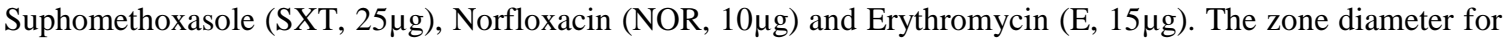
individual antimicrobial agent was then translated into sensitive, intermediate and resistant categories according to the interpretation table of CLSI documents on performance standards for antimicrobial susceptibility testing (CLSI, 2007).

\section{RESULTS AND DISCUSSION}

The present study was designed with a view to find out potential food safety threat associated with raw cow milk collected from Jessore city.

Large microbial load was found in almost every sample of raw milk. The standard limit for microbial counts in raw milk has been set by European Commity (EC) at $1 \times 10^{5} \mathrm{CFU} / \mathrm{ml}$ to $5 \times 10^{5} \mathrm{CFU} / \mathrm{ml}$. Comparing with this, the bacteriological quality for most raw milk samples in this study was poor (Table 1). The highest total viable count (TVC) was $1.95 \times 10^{9} \mathrm{CFU} / \mathrm{ml}$. It may results from poor sanitary conditions of dairy yard, increasing contamination of body surface by feces and soil, lacking of washing of animal and using of unsanitary milking utensils. Even the lowest TVC count was $2.1 \times 10^{7} \mathrm{CFU} / \mathrm{ml}$ which exceeds the limit suggested by EC. This condition indicates the poor local milking system by untrained personnel and defective supply chain. Total viable count found in this study has a strong connection with that of Uddin et al. (2011) who found TVC ranging 2.0 $\times 10^{8}-2.36 \times 10^{9} \mathrm{CFU} / \mathrm{ml}$. The TVC result is also closely related to the finding of Hossain et al. (2010) who stated TVBC ranging $1.75 \times 10^{6}-1.22 \times 10^{8} \mathrm{CFU} / \mathrm{ml}$. Finding of this research also supports the finding of Muhammad et al. (2009) and Yuen et al. (2012) who found TVC of several samples exceeding $10^{6} \mathrm{CFU} / \mathrm{ml}$ and $10^{7} \mathrm{CFU} / \mathrm{ml}$ respectively. However, the present study strongly differs from the findings of Tokar et al. (2008) who found standard plate count of raw milk $4.5 \log 10$ which is much lower than the finding of this study. It may results from the relatively better hygienic status due to organized dairy farm production system, better quality of water and short period of transportation and preparation of sample. 
The coliform count was also high in all the samples (Table 1).

Table 1. Bacterial enumeration of tested samples

\begin{tabular}{llll}
\hline No. of sample & TVC $(\mathrm{cfu} / \mathrm{ml})$ & TCC $(\mathrm{cfu} / \mathrm{ml})$ & TSC $(\mathrm{cfu} / \mathrm{ml})$ \\
\hline 1 & $9.05 \times 10^{8}$ & $1.08 \times 10^{6}$ & $8.48 \times 10^{6}$ \\
2 & $2 \times 10^{9}$ & $5.16 \times 10^{6}$ & $1.56 \times 10^{5}$ \\
3 & $1.95 \times 10^{9}$ & $1.5 \times 10^{7}$ & $8 \times 10^{6}$ \\
4 & $1.03 \times 10^{9}$ & $1.5 \times 10^{7}$ & $5 \times 10^{6}$ \\
5 & $1.14 \times 10^{9}$ & $1.7 \times 10^{6}$ & $1.2 \times 10^{6}$ \\
6 & $2.5 \times 10^{8}$ & $1.5 \times 10^{6}$ & $6 \times 10^{5}$ \\
7 & $6 \times 10^{9}$ & $2.5 \times 10^{7}$ & $3 \times 10^{7}$ \\
8 & $2.7 \times 10^{7}$ & $2 \times 10^{5}$ & $1.2 \times 10^{6}$ \\
9 & $8 \times 10^{8}$ & $1 \times 10^{6}$ & $1.2 \times 10^{5}$ \\
10 & $1.67 \times 10^{8}$ & $5.2 \times 10^{6}$ & $1.02 \times 10^{7}$ \\
11 & $2.1 \times 10^{7}$ & $5 \times 10^{6}$ & $9.5 \times 10^{5}$ \\
12 & $1.5 \times 10^{8}$ & $2 \times 10^{6}$ & $5.2 \times 10^{5}$ \\
\hline
\end{tabular}

Table 2. Biochemical tests for bacterial isolates

\begin{tabular}{|c|c|c|c|c|c|c|c|c|c|c|c|}
\hline \multirow[t]{2}{*}{ Isolates no } & \multicolumn{3}{|c|}{ TSI } & \multicolumn{7}{|c|}{$\mathrm{MIU}$} & \multirow{2}{*}{ 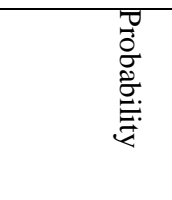 } \\
\hline & $\stackrel{\varpi}{\Xi}$ & $\stackrel{\mathscr{n}}{\stackrel{\Xi}{0}}$ & is & $\stackrel{Q}{\approx}$ & $\begin{array}{l}\stackrel{P}{\vec{*}} \\
\overrightarrow{\tilde{\sigma}}\end{array}$ & 光 & $\frac{\Xi}{\frac{B}{0}}$ & 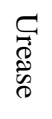 & 光 & $\succsim$ & \\
\hline $\begin{array}{l}1,6,15,16,18,19,21,24,26,30,32,34 \\
39,42,43,44,45,48,51,53,54,59\end{array}$ & $\mathrm{~A}$ & $\mathrm{~A}$ & - & + & + & - & - & + & + & - & $\begin{array}{l}\text { Klebsiella } \\
\text { spp. }\end{array}$ \\
\hline $\begin{array}{l}2,8,9,11,12,13,14,20,33,36,40,46,47,50,58 \\
60\end{array}$ & A & A & - & + & + & + & - & - & - & + & $\begin{array}{l}\text { Enterobacter } \\
\text { spp. }\end{array}$ \\
\hline $3,4,5,7,10,17,22,25,27,37,41,49,55,56$ & A & $\mathrm{K}$ & - & - & - & - & - & - & + & - & Shigella spp. \\
\hline 23 & A & $\mathrm{K}$ & - & + & + & + & - & + & + & - & $\begin{array}{l}\text { Citrobacter } \\
\text { spp. }\end{array}$ \\
\hline $28,29,31,35,38,52,57$ & A & $\mathrm{K}$ & - & + & - & + & + & - & + & - & E. coli \\
\hline
\end{tabular}

Legend: $\mathrm{A}=$ Acidic, $\mathrm{K}=$ Alkaline, $\mathrm{MR}=$ Methyle red, $\mathrm{VP}=$ Voges-Proskaur +=Positive, -=Negative

The highest coliform bacterial count was $2.5 \times 10^{7} \mathrm{CFU} / \mathrm{ml}$. The isolation of coliforms from raw milk sample might be related to the closeness of udder to the anus of the animal since they are normal flora of the intestine and there is tendency of udder and the teat to be contaminated by the animal feces when the animal lie down on it (Edward et al., 2013). The lowest coliform count was $2 \times 10^{5} \mathrm{CFU} / \mathrm{ml} \mathrm{might}$ be due to relatively better hygienic condition but still was not satisfactory. The identification of coliform bacteria, such as $E$. coli, in raw milk is a common indicator of fecal contamination. Their presence in raw milk normally associated with fecal contamination of water sources or poor hygiene practices during milking process. Irregular bathing of animal, feeding of animal in low land, muddy cow yard, unsanitary milking utensil and contamination of body surface by feces could also act as critical factors. Higher prevalence of E. coli was reported by many authors. In Malaysia Yuen et al. (2012) found the presence of E. coli in $47 \%$ of raw milk samples. In India Pant et al. (2013) found $E$. coli in $100 \%$ raw milk samples. Lower coliform count than this study was found in Muhammad et al. (2009) and in Uddin et al. (2011). E. coli normal flora is supposed to be harmless. But some pathogenic strains of E. coli can cause gastroenteritis, urinary tract infection as well as diarrhoea in infants. Although this study found 


\section{U. T. Tasnim and M. T. Islam}

Coagulase-positive Staphylococcus spp. may cause human disease by the production of toxins. The formation of effective level of toxin needs a high number of microorganisms (approximately $10^{5}-10^{6}$ microbes per $\mathrm{ml}$ of food) (IDF, 1994). In this experiment, Staphylococcus spp. were found in all raw milk samples The highest staphylococcal count was $3 \times 10^{7} \mathrm{CFU} / \mathrm{ml}$ which could result from poor hygienic condition of farms of study areas, presence of subclinical mastitis or contamination from respiratory system and body surface. The lowest staphylococcal count was $1.2 \times 10^{5} \mathrm{CFU} / \mathrm{ml}$ in this study. This finding has a close proximity with the finding of Uddin et al. (2011). On the other hand, Yuen et al. (2012) found lower count than this study in a survey hold at Malaysia. These phenomenon might due to improper milking practices among the dairy farmers. So, the samples in this research were not quite acceptable and safe to the consumers since its lowest count exceeds the standard limit. It also indicates that these samples were not prepared under good sanitation practices and were not stored in appropriate storage conditions.

Microbial characterization of randomly selected 60 isolates were performed by biochemical tests and the test results were revealed as Klebsiella spp., Enterobacter spp., Shigella spp., Staphylococcus spp., Escherichia coli and Citrobacter spp. (Table 2).

To find out antibiotic susceptibility, total 12 antibiotics were tested against 22 isolates of Klebsiella spp. and 7 isolates of Escherichia coli. The tested antibiotics were divided into mainly three groups (Table 3 and Table 4).

Table 3. Antibiotic resistance overview of Escherichia coli isolates

\begin{tabular}{|c|c|c|c|c|c|c|c|c|c|c|c|c|}
\hline \multirow{3}{*}{$\begin{array}{l}\text { Isolates } \\
\text { No. }\end{array}$} & \multicolumn{12}{|c|}{ Zone of inhibition (diameter in $\mathrm{mm}$ ) } \\
\hline & \multicolumn{3}{|c|}{$\begin{array}{l}\text { G-I (Cell wall synthesis } \\
\text { inhibitor) }\end{array}$} & \multicolumn{5}{|c|}{$\begin{array}{l}\text { G-II (Protein synthesis } \\
\text { inhibitor) }\end{array}$} & \multicolumn{4}{|c|}{$\begin{array}{l}\text { G-III (Nucleic acid synthesis } \\
\text { inhibitor) }\end{array}$} \\
\hline & AML & CRO & IPM & CIP & $\mathrm{S}$ & TE & $\mathrm{CN}$ & $\mathrm{E}$ & NA & $\mathrm{C}$ & SXT & NOR \\
\hline 28 & 0 & 24 & 22 & 16 & 14 & 20 & 15 & 0 & 14 & 21 & 28 & 18 \\
\hline 29 & 13 & 23 & 16 & 20 & 0 & 20 & 12 & 0 & 21 & 20 & 25 & 20 \\
\hline 31 & 0 & 27 & 20 & 20 & 12 & 18 & 15 & 0 & 23 & 21 & 20 & 25 \\
\hline 35 & 0 & 24 & 21 & 3 & 13 & 15 & 21 & 0 & 22 & 16 & 19 & 28 \\
\hline 38 & 0 & 20 & 20 & 24 & 13 & 17 & 13 & 0 & 18 & 20 & 20 & 25 \\
\hline 52 & 0 & 20 & 23 & 20 & 13 & 20 & 23 & 0 & 10 & 19 & 18 & 15 \\
\hline 57 & 0 & 22 & 25 & 21 & 17 & 15 & 18 & 0 & 23 & 18 & 22 & 24 \\
\hline
\end{tabular}

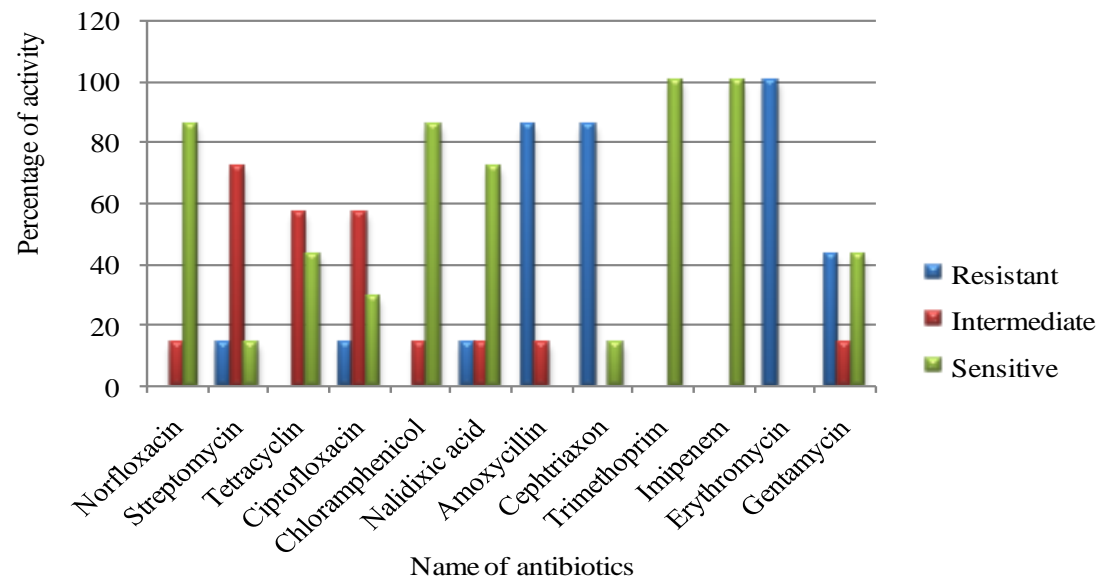

Fig. 1. Antibiotic resistance pattern of Escherichia coli against 12 commonly used antibiotics 
In case of Escherichia coli, $100 \%$ isolates showed sensitivity against Trimethoprim-Sulphomethoxasole and Imipenem. It was followed by Norfloxacin and Chloramphenicol; more than $80 \%$ isolates showed sensitivity against these two antibiotics. $100 \%$ E. coli isolates were resistant against Erythromycin whereas $86 \%$ isolates showed resistance against Amoxycillin and Ceftriaxon. A previous study by Afroz et al. (2013) found E. coli isolates showing $88 \%$ resistance against Erythromycin, that is close to this present study. However, $60 \%$ isolates were found as intermediate against Streptomycin (Fig. 1).

Like E. coli isolates, Klebsiella spp. also showed sensitivity to a number of antibiotics (Ciprofloxacin, Tetracyclin, Norfloxacin, Imipenem, Nalidixic acid) (Fig. 2). Resistance also occured against other antibiotics like Erythromycin, Streptomycin, Chloramphenicol, Trimethoprim, Gentamycin. In a study Nipa et al. (2011) reported that Klebsiella spp. isolates showed resistance against Erythromycin, Gentamycin, Ampicillin, Chloramphenicol and Streptomycin.

Table 4. Antibiotic resistance overview of Klebsiella spp.

\begin{tabular}{|c|c|c|c|c|c|c|c|c|c|c|c|c|}
\hline \multirow[t]{3}{*}{ Isolates No. } & \multicolumn{12}{|c|}{ Zone of inhibition (diameter in $\mathrm{mm}$ ) } \\
\hline & \multicolumn{3}{|c|}{$\begin{array}{c}\text { G-I (Cell wall } \\
\text { synthesis inhibitor) }\end{array}$} & \multicolumn{5}{|c|}{$\begin{array}{l}\text { G-II (Protein synthesis } \\
\text { inhibitor) }\end{array}$} & \multicolumn{4}{|c|}{$\begin{array}{l}\text { G-III (Nucleic acid synthesis } \\
\text { inhibitor) }\end{array}$} \\
\hline & AML & $\begin{array}{l}\mathrm{CR} \\
\mathrm{O}\end{array}$ & IPM & CIP & $\mathrm{S}$ & $\mathrm{TE}$ & $\mathrm{CN}$ & $\mathrm{E}$ & A & $\mathrm{C}$ & SXT & NOR \\
\hline 1 & 0 & 18 & 25 & 20 & 15 & 15 & 17 & 0 & 19 & 21 & 18 & 22 \\
\hline 6 & 0 & 0 & 35 & 30 & 11 & 0 & 20 & 0 & 7 & 10 & 0 & 28 \\
\hline 15 & 0 & 19 & 24 & 25 & 15 & 16 & 18 & 0 & 19 & 23 & 19 & 25 \\
\hline 16 & 0 & 21 & 21 & 23 & 14 & 15 & 21 & 0 & 22 & 20 & 21 & 25 \\
\hline 18 & 13 & 0 & 21 & 26 & 20 & 15 & 23 & 7 & 15 & 24 & 0 & 24 \\
\hline 19 & 15 & 25 & 36 & 25 & 21 & 14 & 15 & 0 & 20 & 21 & 21 & 15 \\
\hline 21 & 0 & 25 & 23 & 15 & 12 & 17 & 14 & 0 & 15 & 24 & 25 & 16 \\
\hline 24 & 0 & 28 & 20 & 18 & 16 & 19 & 17 & 0 & 16 & 22 & 28 & 17 \\
\hline 26 & 0 & 0 & 0 & 25 & 0 & 21 & 0 & 0 & 22 & 20 & 25 & 13 \\
\hline 30 & 0 & 26 & 23 & 28 & 12 & 18 & 15 & 0 & 20 & 22 & 23 & 26 \\
\hline 32 & 0 & 22 & 24 & 30 & 12 & 15 & 14 & 0 & 19 & 24 & 0 & 24 \\
\hline 34 & 20 & 17 & 34 & 26 & 22 & 17 & 26 & 23 & 11 & 24 & 22 & 26 \\
\hline 42 & 0 & 25 & 35 & 23 & 13 & 13 & 24 & 0 & 15 & 12 & 23 & 27 \\
\hline 43 & 15 & 23 & 25 & 29 & 16 & 15 & 20 & 0 & 25 & 25 & 21 & 25 \\
\hline 44 & 0 & 20 & 30 & 20 & 14 & 15 & 15 & 0 & 21 & 22 & 20 & 24 \\
\hline 45 & 30 & 23 & 40 & 27 & 22 & 25 & 28 & 15 & 15 & 20 & 0 & 27 \\
\hline 39 & 0 & 25 & 24 & 30 & 19 & 18 & 20 & 0 & 21 & 26 & 25 & 29 \\
\hline 51 & 15 & 18 & 35 & 25 & 20 & 20 & 26 & 26 & 14 & 25 & 22 & 29 \\
\hline 54 & 0 & 26 & 25 & 21 & 19 & 18 & 26 & 0 & 21 & 22 & 23 & 22 \\
\hline 53 & 0 & 18 & 30 & 30 & 17 & 19 & 20 & 0 & 20 & 28 & 13 & 23 \\
\hline 48 & 12 & 24 & 21 & 23 & 22 & 16 & 20 & 0 & 25 & 22 & 22 & 30 \\
\hline 59 & 20 & 23 & 25 & 26 & 16 & 17 & 20 & 10 & 20 & 27 & 21 & 30 \\
\hline
\end{tabular}




\section{U. T. Tasnim and M. T. Islam}

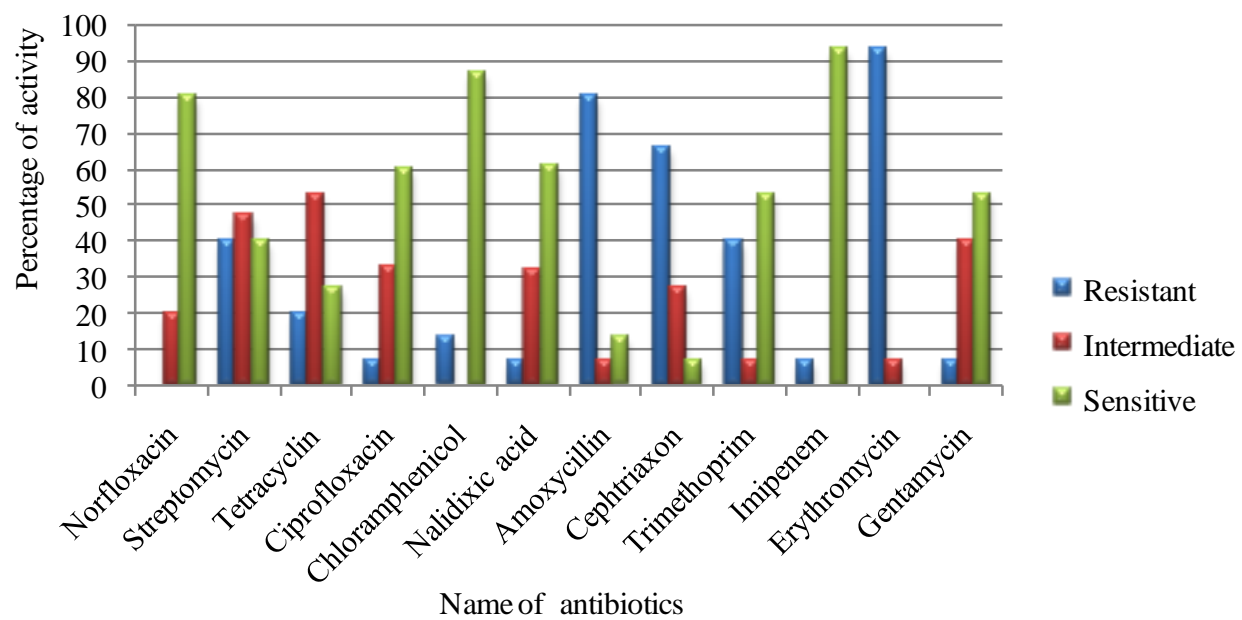

Fig. 2. Antibiotic resistance pattern of Klebsiella spp. against 12 commonly used antibiotics

Among 22 Klebsiella spp. isolates, 96\% exhibited resistance against Erythromycin. However, same percentage of isolates showed sensitivity against Imipenem. Percentage of intermediate isolates remained within 55\% for almost all the antibiotics tested. $80 \%$ Klebsiella spp. isolates were found to be resistant against Amoxycillin. This result finds similarity with Ahmed et al. (2014), who isolated Klebsiella spp., showing high resistence against Erythromycin $(76.23 \%)$ and Amoxycillin $(57.14 \%)$ in antibiotic susceptibility test.

Table 5 shows the antibiotic resistance pattern and multidrug resistance results in the tested isolates of $E$. coli and Klebsiella spp. It shows that all the isolates of E. coli and Klebsiella spp. were resistant to two or more of twelve antibiotics used here. Among 7 isolates of $E$. coli, all of them were multidrug resistant but showing their resistance patterns differently for different antibiotics (Table 5). In case of Klebsiella spp. all of the isolates were also found as MDR. We identified one isolate which was resistant for eight antibiotics (S-TET-E-C-NA-SXTCRO-AML). However, results of this study differ from a previous study of Islam et al. (2010) who found-only $3.12 \%$ isolates to be MDR but the findings of Nipa et al. (2011) who showed $98.06 \%$ isolates to be MDR, has a close proximity with present study. Prevalence of such a large amount of MDR bacteria in food samples is a hurdle to develop a healthy and safe living environment for human.

Table 5. Antibiotic resistance profile for E. coli and Klebsiella spp.

\begin{tabular}{|c|c|c|c|c|c|c|}
\hline \multirow{2}{*}{$\begin{array}{l}\text { No. of resistant } \\
\text { antibiotics }\end{array}$} & \multicolumn{2}{|r|}{$\%$} & \multirow{2}{*}{$\begin{array}{l}\text { Combination of } \\
\text { resistant antibiotics }\end{array}$} & \multicolumn{2}{|r|}{$\%$} & \multirow{2}{*}{$\begin{array}{l}\text { Resistance } \\
\text { classification }\end{array}$} \\
\hline & E. coli & $\begin{array}{l}\text { Klebsiella } \\
\text { spp. }\end{array}$ & & E. coli & $\begin{array}{l}\text { Klebsiella } \\
\text { spp. }\end{array}$ & \\
\hline 8 & - & 1 & $\begin{array}{l}\text { S-TET-E-C-NA- } \\
\text { SXT-CRO-AML }\end{array}$ & - & 4.55 & MDR \\
\hline 6 & - & 2 & $\begin{array}{l}\text { S-IME-CN-CRO-E- } \\
\text { AML }\end{array}$ & - & 9.09 & MDR \\
\hline 5 & - & 1 & CIP-TET-C-E-AML & - & 4.55 & MDR \\
\hline 4 & 3 & 3 & TET-CRO-C-AML & 42.86 & 13.64 & MDR \\
\hline 3 & 3 & 8 & CRO-C-AML & 42.86 & 36.36 & MDR \\
\hline 2 & 1 & 7 & E-AML & 14.28 & 31.81 & MDR \\
\hline Total & 7 & 22 & & 100 & 100 & \\
\hline
\end{tabular}

*MDR=Multi drug resistant 
On the basis of data obtained from this study, a conclusion can be drawn that microbiological quality of most of the raw milk samples collected from different areas of Jessore city were not satisfactory as some pathogenic bacteria such as coliforms (Escherichia coli, Enterobacter spp., Klebsiella spp., Shigella spp., Citrobacter spp.) and Staphylococcus spp. were detected from the samples. The presence of several pathogenic bacteria along with high bacterial loads in some samples not only deteriorate the quality of raw milk but also pose safety issue to consumer. The presence of Klebsiella spp. in raw milk can lead to a wide range of disease states, notably pneumonia, urinary tract infections, septicemia and soft tissue infections. Pathogenic E. coli are occasionally responsible for product recalls due to contamination.

The major causes of microbial contamination of milk are due to milking from infected udders of the cows, unhygienic mechanical milking practices, unclean equipment or poor washing practices and improper storage conditions. Raw milk should properly be pasteurized, so that milk remains free from pathogenic microbes. Proper refrigeration temperature should also be maintained to avoid unwanted contamination.

Moreover, some of the isolated E. coli and Klebsiella spp. isolates were multidrug resistant. Their multidrug resistance pattern is a matter of great concern because these bacteria may no longer be treated with conventional therapeutic drugs and they are also capable of spreading their resistance gene to other bacterial genera. According to some recent research, the emergence of drug resistant microorganisms is one of the most serious health problems in modern society, particularly in Bangladesh (Ahmed et al., 2014 and Tabashsum et al., 2013). Frequent use of antibiotics as medicine and in food of animal has resulted an increase in prevalence of bacterial strains resistant to these antimicrobial agents (Hillier et al., 2002; Ahmed et al., 2014 and Tabashsum et al., 2013). Besides, post-milking contaminations with resistant bacteria from environment and food handlers also might play significant role. So, frequent use of antibiotics should be prohibited. In addition, proper training and hygiene practices during milking including post-milking process should be introduced to the dairy farmers; which could be effective to abolish the bacterial load or contamination of the raw milk.

\section{ACKNOWLEDGEMENT}

We would like to thank Nigarin Sultana, Pravas Chandra Roy and Farhana Huqe for thier significant guidance and support. This work was financed by Jessore University of Science and Technology, Jessore, Bangladesh.

\section{REFERENCES}

1. Ahmed S, Tasnim UT, Pervin S and Islam MT (2014). An assessment of bacteriological quality of some fast food items available in Jessore City and antibiotic susceptibility of isolated Klebsiella spp. International Journal of BioScience 5: 125-130.

2. Afroz H, Sultana F, Fakruddin M, Kamrunnahar, Khan ZUM and Datta S (2013). Isolation of Escherichia coli and Staphylococcus aureus from full cream powder milk sold under market conditions at Dhaka, Bangladesh and their antibiotic susceptibility. Journal of Advanced Scientific Research 4: 27-31.

3. Bauer AW, Kirby WMM, Sherris JC and Turk M (1966). Antibiotic susceptibility testing by standardized single disk method. American Journal of Clinical Pathology 145: 493-496.

4. Bonfoh A, Wasem A, Traore AN, Fane A, Spillmann H, Simbe CF, Alfaroukh IO, Nicolet J, Farah Z and Zinsstag J (2003). Microbiological quality of cows' milk taken at different intervals from the udder to the selling point in Barnako (Mali). Food Control 14: 495-500.

5. Bramley AJ and McKinnon CH (1990). The microbiology of raw milk, In Robinson, R. K. (Ed.), Dairy Microbiology, Vol. 1, Elsevier Science Publishers, London, p. 163-208.

6. Buchanan RE and Gibbon NE (1984). Bergey`s Manual of Determminative Bactariology. William and Wilkins Co. Baltimore, New York.

7. CLSI (2007). Performance standards for antimicrobial susceptibility testing, CLSI Document M100-S17, Wayne.

8. Coorevits (2008). Comparative analysis of the diversity of aerobic-spore-forming bacteria in raw milk from organic and conventional dairy farms. Applied Microbiology 31: 126-140.

9. De Valk H, Delarocque AE, Colomb G, Ple S, Godard E, Grimot P and Desenclos JC (2000). A Community-wide outbreak of Salmonella enteric Serotype Typhimurium infection associated with eating a raw milk soft cheese in France. Epidemiological Infection 124: 1-7. 
10. De Buyser ML, Dufour B, Maire M and Lafarge V (2001). Implication of milk and milk products in foodborne diseases in France and in different industrialized countries. International Journal of Food Microbiology 67(1): 117.

11. Edward KC and Inya IM (2013). The Microbial Quality of Raw Milk from four locations in Abia State, Nigeria. IOSR Journal of Pharmaceutica and Biological Science 5: 30-33.

12. Frazier WC and Westhoff DC (2003). Food Microbiology, $4^{\text {th }}$ edn. Tata McGraw-Hill Publishing Company limited, New Delhi.

13. Harrington P, Archer J, Davis JP, Croft DR, Varma JK and EIC officers. (2002). Outbreak of Campylobacter jejuni infections associated with drinking unpasteurized milk procured through a cow-leasing Program. Wisconsin, 2001. Morbidity and Mortality Weekly Report 51: 548-549.

14. Hillier SL, Magee JT, Howard AJ and Palmer SR (2002). How strong is the evidence that antibiotic use is risk factor for antibiotic-resistant, community acquired urinary tract infection? Journal of Antimicrobial Chemotherapy 50: 241-247.

15. Hossain TJ, Alam K and Sikdar D (2010). Chemical and microbiological quality assessment of raw and processed liquid market milks of Bangladesh. Research Journal of Dairy Science 4: 28-34.

16. ICMSF (1986). Sampling for Microbiological Analysis: Principles and Specific Applications. In Microorganisms in Food, $2^{\text {nd }}$ edn. Blackwell Scientific Publications, UK.

17. IDF(1994). Recommendations for the hygienic manufacture of milk and milk based products, appendix A. Spoilage and pathogenic bacteria in milk based products. International Dairy Federation, Belgium.

18. Islam A, Mazumdar RM, Fakruddin M, Islam S, Nipa MN, Iqbal A and Buiyan HR (2010). Multiple resistant bacteria on fruits from different market of Chittagong city in Bangladesh. Bangladesg Research Publication Journal 4: 342-350.

19. Johnston DW, Bruce J and Hill J (1983). Incidence of antibiotic-resistant Escherichia coli in milk produced in the west of Scotland. Journal of Applied Bacteriology 54: 77-83.

20. Khaton R, Hasnat MA, Rahman S and Rahman MM (2014). Public health safety in relation to microbiological quality of freshly drawn cow's milk in Bangladesh. Bangladesh Journal of Veterinary Medicine 12: 231-236.

21. Muhammad K, Altaf I, Hanif A, Anjum A and Tipu MY (2009). Monitoring of hygienic status of raw milk marketed in Lahore City, Pakistan. The Journal of Animal and Plant Science 19: 74-77.

22. Nipa MN, Mazumdar RM, Hasan MM, Fakruddin M, Islam S, Bhuiyan HR and Iqbal A (2011). Prevalence of multi drug resistant bacteria on raw salad vegetables sold in major markets of Chittagong City, Bangladesh. Middle-East Journal of Scientific Research 10: 70-77.

23. Pant R, Nirwal S and Rai N (2013). Prevalence of antibiotic resistant bacteria and analysis of microbial quality of raw milk samples collected from different regions of Dehradun. International Journal of PharmTech Research 5: 804-810.

24. Tabashsum Z, Khalil I, Nazimuddin MD, Mollah AKM, Inatsu Y and Bari ML (2013). Prevalence of foodborne pathogens and spoilage microorganisms and their drug resistant status in different street foods of Dhaka city. Agriculture Food \& Analytical Bacteriological Journal 3: 281-292.

25. Tolle A (1980). The microflora of the udder. Factors influencing the bacteriological quality of raw milk, International Dairy Federation Bulletin, Document 120.

26. Torkar KG and Teger SG (2008). The microbiological quality of raw milk after introducing the two day's milk collecting system. Acta Agriculturae Slovenica 92: 61-74.

27. Uddin MA, Motazzim-ul-Haque HM and Noor R (2011). Isolation and identification of pathogenic Escherichia coli, Klebsiella spp. and Staphylococcus spp. in raw milk samples collected from different areas of Dhaka city, Bangladesh. Stamford Journal of Microbiology 1: 19-23.

28. World Health Organization (2000). Health Report on Infectious Diseases. Overcoming Antimicrobial Resistance 7: 756-61.

29. Yuen K, Yee CF and Yin FH (2012). Microbiological quality and the impact of hygienic practices on the raw milk obtained from the small-scale dairy farmers in Sabah, Malaysia. International Journal of Agriculture and Food Science 2: 55-59. 